\title{
Power Imbalances in Collective Decision-Making: The Study of Minimum Wage Setting Cases
}

\author{
Elisa Susanti ${ }^{1}$, Heru Nurasa ${ }^{2}$, Ida Widianingsih ${ }^{3}$ \\ ${ }^{1}$ Department of Public Administration, Faculty of Social and Political Sciences, Universitas Padjajaran \\ (email: elisa.susanti@unpad.ac.id) \\ ${ }^{2}$ Department of Public Administration, Faculty of Social and Political Sciences, Universitas Padjadjaran \\ ${ }^{3}$ Department of Public Administration, Faculty of Social and Political Sciences, Universitas Padjadjaran
}

\begin{abstract}
This paper aimed to empirically describe the power imbalances issues in setting the minimum wage in Bandung Regency and West Bandung Regency. Formally, Regional Wage Council has been established based on equality. However, several power imbalances have occurred within it. This paper also aimed to figure out the way to balance the power in collective decision making in the case of minimum wage setting. Furthermore, the research method used in this research was based on qualitative approach. Also, informants in this research were members of Regional Wage Council, employers in the industrial sector, and trade unions/labor unions in Bandung Regency and West Bandung Regency. The results of this study showed that power imbalances empirically existed in the setting of minimum wage. These imbalances were due to the issues of representatives, the number of members, information resources, and uncertainty. Moreover, power imbalances in the setting of minimum wage have led to the government's more dominant role. Under these conditions, the effort required to overcome the problem of imbalance is by increasing trust in the government and the commitment of each party to the rules and collective agreements.
\end{abstract}

\section{Keywords:}

collective bargaining; collective decision making; minimum wage; power imbalances

\section{Introduction}

Power in employment relationship is the most popular issue in industrial relations. In fact, there are several papers on employment relationship. One report written by Hogbin (2006) conveys the difference of perspectives in employment relationship. The first perspective is the imbalance power between employers and employees. The second one refers to balancing the power of employers and employees through regulation of employment relationships. The next is on the most contemporary labor economist who affirms that supply and demand determine wage and the other work requirements. There should not be any reason to consider that employers have power upon their employees. Both parties have their own degree of power to limit each other to stick with the agreement.

Kaufman (2008) reports that there are two different paradigms in industrial relations studies, namely original industrial relations and modern industrial relations. The former concerns about the employment relationship, including labor union sector, human resources management and employment-management relationship. Meanwhile, the latter is about labor unions and related topics, such as collective bargaining, labor-management relations and national labor policy. Referring to Kaufman (2008), the current paper regarding power imbalance aims to enrich the modern 
industrial relations paradigm. This paper empirically describes industrial relations that focuses on collective bargaining that seeks to reach a consensus. Power imbalance can be one aspect that makes a consensus in collective bargaining difficult to reach. If this problem is not resolved, the objective of industrial relations will not be achieved.

Budd et al. (2004) report that the modelling of employment relationship as the issue of collective bargaining questions the distribution of resources and prevailing regulations on the interaction between employers and employees. As a result, companies, labor unions, public policy and procedures of dispute settlement are considered as critical institutions, and as the research subject in the relation of industrial pluralist. A study by Budd et al. (2004) is in line with the modern industrial relations paradigm and is an industrial pluralist view that emphasizes the importance of collective bargaining, including through structuring the distribution of resources and regulations.

In relation with the setting in minimum wage, International Labor Organization (2008) reports that related institution facilitate the setting of minimum wage. Generally, in numerous countries, the wage setting is the form of governance, where there should be agreement and collective bargaining between the parties. Moreover, ILO (2013) states that collective bargaining in employment relationship should be etablished by negotiation. In the setting of minimum wage, collective bargaining should be performed in tripartite institution. ILO (2013) conveys the tripartite as the "equal/ balance" interactive forum to solve problems through decision making.

Based on the concept of Hogbin (2006), the form of collective bargaining as stated by the International Labor Organization reinforces the second view of the power in employment relationship, namely balancing the power between employers and employees through regulation of employment relationships. Based on Kaufman (2008), collective bargaining in work relations is a modern industrial relations paradigm. Based on Budd et al. (2004), the concept of collective bargaining as stated by the International Labor Organization requires that regulations, negotiation procedures, and other conditions are in equal conditions to reach a consensus in decision making.

The legal basis in setting the minimum wage in Indonesia is Law Number 13/2003 on Labor. The minimum wage specified by the Governor and by concerning the recommendation proposed by Provincial Wage Council and/or Regent/Mayor. According to Presidential Decree Number 107/2004 on Regional Wage Council, Council refers to a tripartite non-structural institution that consists of government, employers' association, trade unions and labor unions. On the basis of such regulations, it is implicitly stated that the forum of Regional Wage Council must be equal on the powers among its members. Such equality becomes what the entrepreneurs in Employers' Association Indonesia believe in, that one of the purposes of the association is the establishment of industrial relations based on harmony, dynamism, justice and equality.

Furthermore, this research focused on the setting of minimum wage in Bandung Regency and West Bandung Regency prior to the prevailing Government Regulation Number 78/2015 on Wage. Bandung Regency and West Bandung Regency are regions included in Metropolitan Bandung Raya, along with Bandung City, Cimahi City and Sumedang Regency. Based on the Bandung Regency Statistics Center (BPS), most of regions in Metropolitan Bandung Raya engage in the industrial sector. Bandung Regency is a region with the largest industrial sector (51.82\%) compared to the other regions, followed by Cimahi City (47.41\%) and West Bandung Regency (39.59\%). Prior to 2007, Government of Bandung Regency was the master in labors' wage within the area of West 
Bandung Regency, Cimahi City and Sumedang Regency. In fact, West Bandung Regency is the result of expansion of Bandung Regency. Based on data from the Labor Office, after such expansion, labors made frequent strikes because of the policy difference between the government of Bandung Regency and West Bandung Regency.

Actually, the setting of minimum wage in Bandung Regency and West Bandung Regency encountered a number of problems. A problem that occurred every year was the unachieved amicably deliberation. Based on data from the Activity Report of the Wage Council, there was also a difference found in the proposal of minimum wage between Apindo and labor unions in the Regional Wage Council. In the end, the labor unions' strike occurred in response to the failure of an unachieved demand.

Research on industrial relations in Indonesia was carried out mostly in the study of the original industrial relations paradigm. One of those studies was conducted by Ibrahim (2016), which emphasized the role of labor unions in providing protection and defending the rights of workers. Research conducted by Taufiq and Hidayat (2011) and also Utami (2013) concerned the role of labor unions in resolving disputes regarding termination of employment with companies. There are also various studies that have been carried out regarding collective bargaining, such as a study by Lamarche (2015) on collective bargaining in developing countries and a research by Kehinde et al. (2012) regarding collective bargaining in Nigeria. Both studies emphasized collective bargaining on a bipartite basis. A research on collective bargaining in wage determination was carried out by Hayter (2009), who expressed concerns that bipartite collective bargaining would reduce the wage structure and reduce income distribution, which was also related to the weak bargaining power of workers.

The present study has several differences from previous studies. In addition to enriching the modern industrial relations paradigm, this research is also related to collective bargaining in the process of setting minimum wages carried out tripartite by focusing on power imbalances.

Therefore, this study aimed to (1) provide an empirical description of the issues of power imbalances in the setting of minimum wage in Bandung Regency and West Bandung Regency, (2) figure out the way to balance the power in a collective decision making in the case of minimum wage setting.

\section{Literature Review}

In the paper proposed by Ackers (2014), he figures out that there are various perspectives in comprehending industrial relations. The Marxist perspective of industrial relations emphasizes the conflict of interest between capital and labor. The next one is Classical pluralist, which emphasizes the importance of collective bargaining in industrial relations. Thus, the Pluralist perspective in industrial relations emphasizes the equal balance of power. The other one is radical-pluralist, which emphasizes that each work relation refers to "economic exchange" and "power relationship" between the parties; in this case, the superiors and subordinates. However, superiors have greater resources than their subordinates.

Ackers (2014) reports that in its current development, some objections are proposed against the perspective of radical pluralist. One of them is the fact that there are a lot of labor unions obtaining the sturdy bargaining power such as the labor unions' strike. In short, the power balance may be altered because of the strike. There is a limited explanation on industrial relations by numerous perspectives, so Ackers chooses to convey his neo-pluralist perspective. This perspectives suggests five solutions to explain issues on power and conflict in industrial relations; they are: 1) a Weberian ideal type, 2) a neo-pluralist expansion, 3) a 
historical institutional method, 4) a constructive approach to public policy: partnership at work, 5) a normative vision.

In relation with the setting of minimum wage involving numerous parties, the writers refer to literatures on public policy. The involvement of multiple parties in a collective decision-making process is known as policy network, as conveyed by Howlett and Ramesh (1995), and Compston (2009). The other term on collective decision making is also called collaborative governance, as conveyed by Ansell and Gash (2007); Wanna and O'Flynn (2008); O'Leary, Slyke and Kim (2010); Choi and Robertson (2011).

Howlett, Mukherjee, \& Koppenjam (2015) report that the old concept of the theory of policy network may be comprehended in the pattern of interaction to many groups of society and governmental actors. The impact of the policy network is the function of its members' power, in which it depends on the way to distribute the resources and the existence of "rules of the game" as the characteristics of policy network. As the effect, power distribution becomes a significant issue in formulating the policy.

Provan and Kenis (2008) denotes on the issue of power distribution in the form of network governance consisting of: participant governed, lead organization governed, and network administration organization governed. The form of this imbalance network is lead organization governed, and network administration organization governed.

Based on Provan and Kenis (2008) in the previous paragraph, participant-governed network refers to the form of collective balance network, which is regulated by its own members. This form of network will be more effective to accomplish the outcome when trust is widely spread between the members and higher level of consensus. Lead Organization-Governed Networks means the extreme side of Participant-governed network. This form of network occurs when more powerful and less powerful parties exist at the same time. In this form, all network activities and decision making should be coordinated by the members or leader of the organization. The form of Lead OrganizationGoverned Networks would be more effective to accomplish the outcome when the low degree of trust may be divided among the members and the higher degree one towards the centralization. The consensus should be in the low-intermediate one. Network Administrative Organization refers to the form of network containing separated units to regulate the network and its activities. Similar to Lead Organization-Governed Networks, this form of network should be centralized. Such separated units act as the facilitator in coordinating and maintaining the network.

Provan and Milward (2001, p. 419) indicate that the power imbalances occur in a disproportionate organization in terms of resources or authority. This imbalance may also occur when one of the organizations directly control the fund to the other organization within the network. Furthermore, power imbalance is also discussed in collaborative governance. As addressed by Ansel and Gash (2007, p. 551), "If some stakeholders do not have the capacity, organization, status, or resources to participate, or to participate on an equal footing with other stakeholders, the collaborative governance process will be prone to manipulation by stronger actors." Choi and Robertson (2011, p. 2) also considers that, "The decision process may still be dominated by the most powerful actors and interests pertinent to the situation being addressed."

Based on these descriptions, power balance and imbalance can be seen from various aspects. Some aspects to analyze power balance and imbalance in collective decision making are: flow of funds in a network, form of the network, whether the network is decentralized or centralized with asymmetrical power (Provan and Kenis, 2008), the proportion in 
term of resources or authority (Provan and Milward, 2001), capacity, organization, status, and resources to participate (Ansell and Gash, 2007). In details, Ansell and Gash (2007) define the following several aspects to analyze the imbalances of this authority and resources: 1 ) representative organization in the collaboration process (Buanes et al., 2004; Rogers et al., 1993), 2) the ability to negotiate (Gunton and Day, 2003; Lasker and Weiss 2003; Merkhofer, Conway, and Anderson 1997; Murdock, Wiessner, and Sexton 2005), and 3) time and energy allocated for collaboration (Yaffee and Wondolleck, 2003).

Information and capacity by the actors also become the key resources in the formulation of collective policy. As Clarkson et al. (2007, p. 828) state, asymmetric information occurs when one of the parties has greater information relating to the condition provided to the other participating party. Huffman (2009, p. 1) expresses that, "With information being imperfect, the uniformed agents can easily make bad decisions." The information asymmetry, and the capacity obtained among the actors would cause the uncertainty in the decision making and opportunistic behavior. Koppenjan and Klijn $(2004$, p. 6) show that uncertainty occurs when the actors are required to face the social problems and do not have any clue upon the effect of their effort in solving such problems. Qu and Loosemore (2013, pp. 415-421) define opportunistic behavior as the self-interest with deceit. Also, this behavior occurs due to the uncertain environment, imperfect monitoring, asymmetric information, commitment insufficiency and self-gain.

To solve asymmetric information, Clarkson et al. (2007, p. 829) reveal that the access to information through technology or education training may result in the intended solution. In addition, Faria and Silva (2013, p. 1088) state that such solution may be obtained through regulations and procedures to adopt transparent process.
The key point in solving issues regarding power imbalances should be the development of effective collaborative governance conveying the way to facilitate the decision making among different stakeholders. Choi and Robertson (2011) think that consensus may help to balance the power among the stakeholders, but of course, with more resources, information, legitimacy and prestige so that they have sufficient capacity to establish the process of consensus development for their own interest. As the effect, to accomplish the consensus in decision making, the role of facilitators in balancing the authorities among the stakeholders is definitely required. As conveyed by Provan and Milward (2001); Ansell and Gash (2007, p. 551), when the power imbalances arise, the role of leader as the element of successful collaboration is needed.

The present study uses the concepts of Ansell and Gash (2007) as a guidance theory, with several aspects to analyze power imbalances; namely: representative organizations, ability to negotiate, and resources to participate. Two of the decisive resources in the process of determining minimum wages are data and information. Therefore, this study uses the concept of information asymmetry related to uncertainty as stated by Clarkson et al. (2007).

\section{Methods}

The method used in this research was qualitative approach since the purpose of this research required the writers to explore. Such method was also chosen because it correlated with a number of characteristics contained in qualitative research based in Creswell (2009). Furthermore, the data in this research originated from field and secondary data. The writers collected the field data through: (1) unstructured and semi-structured interviews, and (2) observation, in which the writers conducted the observation as non-participant. In addition, the observation was conducted 
during meetings on the setting of minimum wage for the 2015 Employee Minimum Wage in Bandung Regency. Meanwhile the secondary data was collected from (1) study of documentation (qualitative document) consisting of public documents (mass media, minutes and official reports from Regional Wage Council) and private documents (letters addressed to Regional Wage Council), and (2) study of literature.

The informants of this research were related parties of the setting of minimum wage consisting of: (1) Members of Regional Wage Council from the governmental elements: Office of Manpower of Bandung Regency and West Bandung Regency, (2) Members of Regional Wage Council from the representatives of the Bandung Regency Apindo (employers' associations of Indonesia), (3) Members of Regional Wage Council from labor unions (SPSI and SPN), (4) Labor Unions (PUK, SPSI, PUK, SPN, PUK Gaspermindo, PUK SPBMI, and (5) Entrepreneurs in Bandung Regency.

Meanwhile, the writers performed the data validation technique through the confirmation of statements by informants and the studied documents. The data testing in the technique of triangulation were the crosscheck medium towards the obtained data. Moreover, the data analysis includes the data preparation, coding (grouping based on the compiled theme, research findings and data reduction), narration and interpretation.

\section{Results and Discussion}

Formally, Regional Wage Council established on a trust that this forum is based on balance. In its implementation, the Wage Council is faced with the problem of power imbalances. The following are the empirical conditions of power imbalances in minimum wage setting in Bandung Regency and West Bandung Regency, as well as efforts made to balance power in collective decision making in minimum wage setting.

\section{Representative Organizations}

The Indonesian Government has developed infrastructures in this representation through several regulations including Presidential Decree No. 107/2004 on Regional Wage Council, Ministerial Decree No. 201/2001 on Representation in Industrial Relations Institutions, and Regulation of Ministry of Manpower and Transmigration No. 6/2005 on Guideline on the Verification of Labor Union Membership.

Based on the Presidential Decree No. 107/2004 on Regional Wage Council, the element of the members of Regional Wage Council consists of government, employers' association, and labor union with the comparison 2:1:1 added with higher educations and the experts. Subsequently, the member candidates must meet the following criteria:

1. Be an Indonesian citizen

2. Obtain a D3 degree at minimum.

3. Have sufficient experience and insight in the field of payment and human resources development

Based on the above regulation, the government of Bandung Regency and West Bandung Regency stipulate SP TSK SPSI and SPN as the representatives of labor unions in the region. The representatives of companies in Bandung Regency and West Bandung Regency for the members of Regional Wage Council are from Apindo of Bandung Regency and Apindo of West Bandung Regency.

The form of representative organization also depends on the perspectives by the other labor unions. Based on the results of the interview, the informant who was a member of the same trade union but not a member of the Wages Council stated that, "If the recruitment is carried out by involving the officers of work units in Bandung Regency in determining who will sit on the wage council with some sort of selection system, I think it will produce acceptable decisions. But in reality, now as if the membership of the wage council 
was only directly appointed, does not consider the selection procedure."

There are lots of perspectives by the Labor Unions, outside such union who represent the labors in Regional Wage Council. The informant stated that "The union members in the Wage Council are not satisfying, because most workers are bribed by Apindo." Another informant expressed the same thing: "The union members in the Wage Council do not represent all workers, because they mostly have vested interest so that grassroots workers are not satisfied with them." There are also different views from unions outside the wage council members; for example, one view is that union members in the Wage Council are considered to be fairly representative because they have a large number of members. As based on the results of interviews with other informants, who said, "Yes, right, representative. Because those who sit on the Wage Council are from unions with the most members."

In case of Apindo's representation in the Council, entrepreneurs as the members of Apindo engaging in large-scale business consider that Apindo has represented the labor unions. An informant from a large company stated, "Apindo is highly representative, and is very dominant in negotiations to determine minimum wages. They must have certain requirements, so they have met the requirements." However, the non-members of Apindo do not agree with the consideration. Different views are found among small and medium enterprises and are not members of Apindo. Informants from small companies stated, "Did not join Apindo, because Apindo members have to follow the minimum wage standard; if I follow the minimum wage but cannot compete at the same level as foreign companies, the factory will go bankrupt." The same thing was stated by informants from medium-sized companies: "I do not know the benefits of being a member of Apindo, because it seems that business continuity must be resolved personally. Usually, the entrepreneurs who join Apindo are entrepreneurs who have large factories, entrepreneurs like me may not even be considered by organizations to be invited."

Based on the results of interviews with the Secretary of Apindo Bandung Regency, out of 1800 companies listed in Bandung Regency, only 78 companies joined Apindo (4.3\%), and even then, it was dominated by large companies and a few medium-sized companies. The low condition of the company's participation in Apindo also occurs at the provincial level. The chairman of Apindo West Java stated that there were thousands of companies in West Java that were not yet members of Apindo. The number of companies that are not yet members of Apindo is about three times the total membership.

\section{Education and Negotiation Skill}

Based on the data in the Regent Decree Regarding the Membership of the Wage Council, the following is the composition of the membership and educational background of the Wage Council of Bandung Regency and Wage Council of West Bandung Regency.

As stated earlier that one of the requirements to become a member of the Wage Council is to have the lowest education of D3. So, it can be concluded that members of the Wage Council in Bandung Regency have met the education requirements. In the elements of government and Apindo in Bandung Regency, there are members who have an educational background in economics, so they understand the theory and issues regarding economics. In West Bandung Regency, there are members of the Wage Council who are from elements of workers' organizations and who do not meet the education requirements.

The selection for the members of Regional Wage Council from the labor union element must also be specified based on negotiation skill and the career path as the administrators of Head of Branch. According to the observation conducted during the meeting of Regional Wage Council, the writers figured out that all 
Table 1.

Membership Composition and Educational Background of the Wage Council of Bandung Regency and Wage Council of West Bandung Regency

\begin{tabular}{|c|c|c|c|c|}
\hline \multirow{2}{*}{ No } & \multicolumn{2}{|c|}{ Wage Council of Bandung Regency (2015-2018) } & \multicolumn{2}{|c|}{ Wage Council of West Bandung Regency (2014-2017) } \\
\hline & Organization Unit & $\begin{array}{l}\text { Educational } \\
\text { Background }\end{array}$ & Organization Unit & $\begin{array}{l}\text { Educational } \\
\text { Background }\end{array}$ \\
\hline \multirow[t]{9}{*}{ I } & Government & & Government & \\
\hline & 1. Head of Manpower Office & Master & $\begin{array}{l}\text { 1. Head of Social, Manpower and } \\
\text { Transmigration Office }\end{array}$ & Master \\
\hline & 2. Manpower Office & Master & $\begin{array}{l}\text { 2. Office of Social, Manpower and } \\
\text { Transmigration Working }\end{array}$ & Master \\
\hline & 3. Manpower Office & Master & 3. Law Section of Regional Secretariat & Masters \\
\hline & 4. Central Statistics Agency & Bachelor & 4. Central Statistics Agency & Bachelor \\
\hline & $\begin{array}{l}\text { 5. Office of Cooperatives, SMEs, } \\
\text { Trade and Industry }\end{array}$ & Bachelor & $\begin{array}{l}\text { 5. Regional Development Planning } \\
\text { Board }\end{array}$ & Bachelor \\
\hline & $\begin{array}{l}\text { 6. Law Section of Regional } \\
\text { Secretariat }\end{array}$ & Bachelor & $\begin{array}{l}\text { 6. Office of Industry, Trade, } \\
\text { Cooperative and SME }\end{array}$ & Bachelor \\
\hline & $\begin{array}{l}\text { 7. Economic Coordination Section } \\
\text { of Regional Secretariat }\end{array}$ & Magister & & \\
\hline & 8. Manpower Office & Magister & & \\
\hline II & Apindo of Bandung Regency & $\begin{array}{l}1 \text { Master and } \\
3 \text { Bachelor }\end{array}$ & Apindo of West Bandung Regency & 3 Bachelor \\
\hline III & Labor Unions & $\begin{array}{l}1 \text { Master and } \\
3 \text { Bachelor }\end{array}$ & Labor Unions & 3 High School \\
\hline \multirow[t]{2}{*}{ IV } & Experts/ College & Masters & Experts /College & Doctoral \\
\hline & Total Number & 17 people & & 13 people \\
\hline
\end{tabular}

Source: Processed from Bandung Regent Decision Regarding Membership of Bandung Regency Wage Council Year of 2015-2018, and West Bandung Regent Decision Regarding Board Structure and Personnel West Bandung Regency Wage Year of 2014-2017.

members of the Council from labor unions had negotiation skill. The writer found out such skill based on the way they delivered the opinions as well as strategies. However, the negotiation skill was not followed by the insight and measurement of the condition of macro-economy as the basis of measurement in setting the minimum wage. In relation to the process of such recruitment, the education was not included as an absolute requirement, since the Head of Branch directly determined the result.

\section{Information Asymmetry and Uncertainty}

Based on observations on the minimum wage setting meeting, in the process of the setting of minimum wage, Apindo would have information in relation with the company's condition. Also, during such process, the Apindo frequently state that the companies' condition is not well, and they propose the value of minimum wage within the lower limit, but without describing the company's data. Although such information is confidential and not considered as the measurement in setting the minimum wage, transparency upon the company's condition becomes one determiner in setting the minimum wage and may result in trust improvement between the parties. Information asymmetry in setting the minimum wage occurs when the other party is not able to access private information. This is somehow in line with Huffman $(2009$, p. 3) who states that private information is a type of information asymmetry.

Other than information asymmetry, the setting of minimum wage in Bandung Regency and West Bandung Regency must also face uncertainty. Uncertainty originates from the insufficient capacity (education obtained by 
the involved party) and information. This uncertainty also occurs when the parties have different perceptions due to different reference or interpretation (Koppenjan and Klijn, 2004).

Uncertainty occurs in relation with the formulation in setting the minimum wage. Law No. 13/2003 Article 89 states that the "Government shall specify the minimum wage based on the appropriate necessity of life and by considering the productivity and economic growth." Other than multiple interpretations towards the formulation in setting the minimum wage, the data of macro economy is considered less supporting. The data of economy and statistics related to the setting of minimum wage is centralized in Central Bureau of Statistics (BPS). The problem arises when the data issuance by BPS is considered as inaccurate by Apindo. Somehow, Apindo are more critical against the data issued by BPS.

\section{Implications of Power Imbalances in Setting the Minimum Wage}

Based on observations of the minimum wage setting meeting and based on the author's analysis, the imbalances in setting the minimum wage, particularly in education and capacity sides, as well as the information asymmetry and uncertainty, results in less irrational setting of minimum wage. In other words, the setting would not be based on the measurement of minimum wage, since the formulation may cause multiple interpretation, and the less supporting data issued by BPS. To reduce such uncertainty, the parties use such strategy as formulation by negotiation.

This condition is in line with a statement from Ostrom and Ostrom (1971), which says that when uncertainty occurs, individuals will adopt a series of diverse strategies to reduce the level of uncertainty. The application of this strategy shows a less rational decision-making process. The implications of power imbalances in determining minimum wages also lead to opportunistic behavior. As stated by Qu and Loosemore (2013), opportunistic behavior arises from environmental uncertainty, imperfect supervision, information asymmetry, lack of commitment, and self-seeking interests.

Apindo use an economic principle so that they propose a low value of minimum wage. Meanwhile, labor unions propose a higher value to accomplish the wellbeing. This proposal of higher value is also supported by the other labor unions in the agglomeration area of Metropolitan Bandung Raya. In the event a proposal fails, they go on strike for what they believe in.

This action by Labor Unions affects the process of the setting of minimum wage. In Bandung Regency, the setting in minimum wage in 2013 was specified by the regent. Similar to it, the governor specified the minimum wage in 2014 and 2015. Such changes were due to the strike by labor unions. In the end, it resulted in Apindo's distrust to labor unions. Such distrust apparently affected the setting of minimum wage in the following year. Negotiation was no longer used since Apindo worried that the government would change the decision. At last, the consensus would be more difficult to reach. Conditions in West Bandung Regency are not more conducive than in Bandung Regency. More strikes occur in West Bandung Regency compared to Bandung Regency, and consensus is more difficult to achieve.

From this case of setting minimum wages, it can be seen that there are various implications of power imbalances. The implication of power imbalances is that more decisions are made based on the strategies of each party so that decision making becomes less rational. Because decision is made predominantly based on strategy, a consensus is more difficult to achieve, and going on strike appears as a form of disagreement. In conditions of regulations that are difficult to enforce, there will be more opportunistic behavior. This continuing condition, in the long run, creates distrust and 


\section{Chart 1.}

Conditions of Power Imbalances in Bandung Regency and West Regency and Their Implications on Collective Decision Making
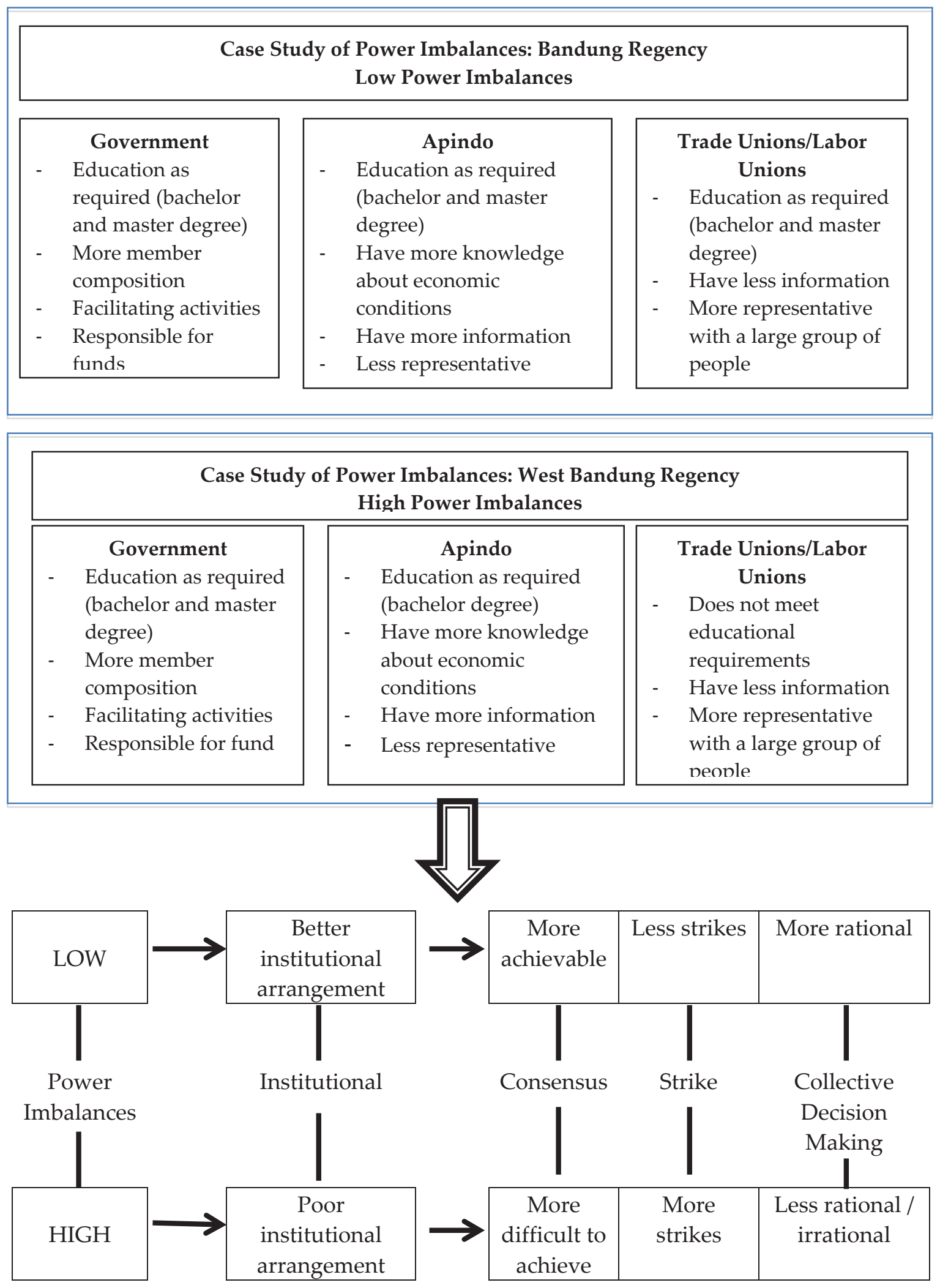

Source : obtained from data analysis 
makes collective bargaining more difficult. The power imbalances' conditions in determining minimum wages in Bandung Regency and West Bandung Regency and their implications in collective decision making are illustrated in the following chart 1 .

\section{Efforts to Overcome Power Imbalances in Collective Decision Making}

Bandung Regency is an interesting case in an effort to overcome power imbalances. Although there are differences in power and problems in minimum wage determination in Bandung Regency, history shows that there are efforts from all parties involved to achieve better industrial relations in the region. Based on the author's analysis of the results of observation, interviews and comparing the Activity Report of the Wage Council of Bandung Regency and West Bandung Regency, The Wage Council of Bandung Regency has an institution that is better organized. There is clarity of regulations in various stages of activities and the formation of regulations are mutually made based on consensus. Bandung Regency also has a more balanced position of power compared to West Bandung Regency. Bandung Regency often gets visits from other regional Wage Councils because they are considered conducive in wage setting.

The Wage Council of Bandung Regency was once an exclusive forum in determining minimum wages in 2012, where there was no change in the value of wages by either the regent or the governor. As a result, in determining the minimum wage for the following year, namely in 2013, an agreement was reached within the Wage Council through the negotiation process in the recommendation for the first wage.

Consensus can be achieved because it prioritizes dialogue in various stages of minimum wage determination, namely starting from the rules, Decent Living Needs (KHL) determination, and minimum wage determination. Conduciveness at that time can occur because each party respects the results of the decision, in the sense that there is no change in recommendations, either by the regent or by the governor. Another key to success in overcoming the problem of power imbalances is the role of the leader, who can embrace all parties so that they get support from all parties. Referring to Ansell and Gash (2007), leadership is important to establish and maintain clear basic rules, build trust, facilitate dialogue, and explore mutual benefits.

Consensus can be achieved in the cases of minimum wage determination in 2012 and 2013. However, the community is still faced with strikes carried out by unions in Bandung Regency. Actually, the strike carried out was a form of union solidarity with other regions in Metropolitan Bandung Raya, which was the effect of agglomeration. The strike was not intended for the Bandung Regency Government, but was carried out as a form of solidarity with other unions in the Metropolitan Bandung Raya.

Since the determination of the 2016 minimum wage, the central government has set a step to overcome various problems in setting minimum wages through the establishment of Government Regulation Number 78/2015 on Wage. This government regulation seems to reduce the involvement of local governments in determining minimum wages. The social learning aspect at the regency/city government level is meaningless because there is a lack of democratic processes and collective bargaining to achieve a solution where all parties benefit. Caraway and Ford's research (2017) revealed that through Government Regulation Number 78/2015 on Wage, national governments took action to weaken trade unions, avoiding the wage council by increasing wages according to the formula based on inflation and growth in gross domestic product. This may lead to weaken cooperation in the industrial field.

\section{Conclusion}

The first conclusion of the present study is that the setting of minimum wages in Indonesia 
through the Wage Council is included in the form of a lead organization governed, that is an imbalance form of network where there are strong parties and weak parties. Strong parties are from the government element. The government facilitates activities, is responsible for funds, and has a composition of more members so that they will be able to determine decisions if there is a vote. The government also has a decisive role because the minimum wage is set by the governor through the recommendation of the regent. Employers are often considered to be stronger because they have capital and information resources. But empirically, the labor union has the power of being representative and through strikes involving a large group of people. The strength of the labor union also comes from solidarity in the Metropolitan Bandung Raya. In this regard, this study has limitations, as it has not revealed how the strength of regional solidarity can be formed, and what factors or motives encourage workers to form calculated forces. This condition is certainly different from the employers' organization, where there is a lack of solidarity even though it is in the same area, which is Metropolitan Bandung Raya.

Minimum wage setting in Indonesia is an imbalance form. Conditions in Bandung Regency are more balanced than in West Bandung Regency. From this case, it can be concluded that in more imbalanced conditions, there will be more strikes, the potential for conflict will be greater, a consensus will be more difficult to produce, and the process of collective decision making will be irrational.

The second conclusion of this study is that power imbalances can be overcome through the formation of a consensus among the parties involved and institutional arrangements. When power imbalances occur, information asymmetry occurs and there is low trust among stakeholders. Thus, trust in the leader is needed. Leaders play a role in balancing strength among stakeholders, one of which is to ensure the achievement of a consensus, and ensure that agreed rules can be implemented properly. A consensus is also formed through better institutional arrangement, agreement with rules, clarity of rules in the process of collective decision making, and data and information support. Another aspect that also determines is the commitment and willingness of each party to comply with and accept the results of the decision.

There are two suggestions proposed based on the findings of this study. Firstly, one suggestion from a practical point of view is to maintain collective bargaining in industrial relations, especially in determining minimum wages as intended by the International Labor Organization $(2008,2013)$. Power imbalances cannot be overcome by eliminating the role of the parties involved, but through better institutional arrangements. This is intended to create harmonious, dynamic and equitable industrial relations based on the principles of Pancasila democracy. Secondly, the results of this study present a phenomenon regarding regional strength (agglomeration) as one aspect that can be reasonably calculated. A second suggestion for further study is to study more comprehensively about the concept of agglomeration or spatial interaction so that it can form both economic power and solidarity in a region.

\section{References}

Ackers, P. (2014). Rethinking the employment relationship: A neo-pluralist critique of British industrial relations orthodoxy. The International Journal of Human Resource Management, 25(18), 2608-2625.

Ansell, C., \& Gash, A. (2007). Collaborative governance in theory and practice. Journal of Public Administration Research and Theory, 18, 543-571.

Bandung Regent Decree Number: 561/Kep.182Disnaker/2015 concerning Appointment of Members of Wage Council and 
Members of Wage Council Secretariat of Bandung Regency for the 2015-2018.

Budd, J. W., Gomez, R.., \& Meltz, N. M. (2004). Why a balance is the best: The pluralist industrial relations paradigm of balancing competing interest. Paper presented at Theoretical Perspectives on Work and the Employment Relationship, Berlin. Retreived from http://jbudd.csom.umn. edu/RESEARCH/buddgomezmeltz.pdf

Buanes, Arild, Jentoft, S., Karlsen, G. K., Maurstad, A., \& Søreng, S. (2004). In whose interest? An exploratory analysis of stakeholders in Norwegian coastal zone planning. Ocean \& Coastal Management, $47,207-23$.

Caraway, T., \& Ford, M. (2017). Institutions and collective action in divided labour movements: Evidence from Indonesia. Journal of Industrial Relations, 59(4), 444464.

Choi, T., \& Robertson, P. J. (2011). Caucuses in collaborative governance: The effects of structure, power, and problem complexity. International Public Management Journal, 17(2). 224-254.

Clarkson, G., Jacobsen, T., \& Batcheller, A. (2007). Information asymmetry and information sharing. Government Information Quarterly, 24, 827-839.

Compston, H. (2009). Policy networks and policy change: Putting policy network theory to the test. New York: Palgrave Macmillan.

Creswell, J. W. (2009). Research design: Qualitative, quantitative, and mixed method approaches. California: Sage.

Faria, J.A., \& Silva, S. (2013). The effects of information asymmetry on budget slack: An experimental research. African Journal of Business Management, 7(13), 1086-1099.

Gunton, T. I., \& Day, J. C. (2003). The theory and practice of collaborative planning in resource and environmental management. Environments, 31(2), 5-19.
Hayter, S. (2009). A fair globalization: The role of collective bargaining in stemming the rising tide of inequality in earnings and income. International Journal of Labour Research, 1(2), 27-42.

Hogbin, G. (2006). Power in employment relationships: is there an imbalance? New Zealand: New Zealand Business Roundtable.

Howlett, M., Mukherjee, I., \& Koppenjan, J. (2015). Policy learning and policy networks in theory and practice: The case of Indonesian biodiesel policy network. Paper presented at the PL\&PC panel of the ICPP conference, Milan.

Howlett, M., \& Ramesh. (1995). Studying public policy: Policy cycles and policy subsystem. New York: Oxford University Press.

Huffman, W. E. (2009). Does information change behavior?. Paper presented at the 3rd OECD World Forum on "Statistics, Knowledge and Policy". Busan, Korea.

Ibrahim, Z. (2016). Eksistensi serikat pekerja/serikat buruh dalam upaya mensejahterakan pekerja. Jurnal Media Hukum, 23(2), 150-161.

International Labour Organization (ILO). (2013). National tripartite social dialogue: An ILO guide for improved governance. Geneva: International Labour Organization.

International Labour Organization (ILO). (2008). Global wage report 2008/2009 minimum wages and collectivebargaining: Towards policy coherence. Geneva: International Labour Organization

Kaufman, Bruce E. (2008). Paradigms in industrial relations: Original, modern and versions in-between. British Journal of Industrial Relations, 46(2), 314-339.

Kehinde, A., Ogundeji, M., \& Felix, A. (2012). The current status of collective bargaining and its implications on bottom-line performance in Nigeria oil and gas industry. Journal of Humanities And Social Science, 3(6), 18-38. 
Koppenjan, J., \& Klijn, E.H. (2004). Managing uncertainties in networks: A network approach to problem solving and decision making. New York: Routledge

Lamarche, C. (2015). Collective bargaining in developing countries negotiating work rules at the firm level instead of the industry level could lead to productivity gains. Retrieved from https://wol.iza.org/articles/ collective-bargaining-in-developingcountries/long

Lasker, R. D., \& Weiss, E. (2003). Broadening participation in community problemsolving: A multidisciplinary model to support collaborative practice and research. Journal of Urban Health, 80, 14-60.

Menteri Tenaga kerja dan Transmigrasi. (2001). Keputusan Menteri Tenaga Kerja dan Transmigrasi Republik Indonesia Nomor Kep-201/MEN/2001 Tentang Keterwakilan dalam Kelembagaan Hubungan Industrial. Jakarta: Menteri Tenaga Kerja dan Transmigrasi Republik Indonesia.

Menteri tenagakerja dan Transmigrasi Republik Indonesia. (2005). Peraturan Menteri Tenaga Kerja dan Transmigrasi Republik Indonesia Nomor: PER.06/MEN/IV/2005 Tentang Pedoman Verifikasi Keanggotaan Serikat Pekerjal Serikat Buruh. Jakarta: Menteri Tenaga Kerja dan Transmigrasi Republik Indonesia.

Merkhofer, M. W., Conway, R., \& Anderson, R. G. (1997). Multiattribute utility analysis as a framework for public participation in siting a hazardous waste management facility. Environmental Management, 21, 831-839.

Murdock, B., Wiessner, C., \& Sexton, K. (2005). Stakeholder participation in voluntary environmental agreements: Analysis of 10 project XL case studies. Science, Technology \& Human Values, 30, 223-250.

O'Leary, R., Slyke, D. M., \& Kim, S. (2010). The future of public administration around the world. Washington D.C: Georgetown University Press.
Ostrom, E.,\& Ostrom, V. (1971). Public choice: A different approach to the study of public administration. Public Administration Review, 31(2), 203-216.

Presiden Republik Indonesia. (2004). Keputusan Presiden Republik Indonesia Nomor 107 Tahun 2004 Tentang Dewan Pengupahan. Jakarta.

President of The Republic of Indonesia. (2015). Government Regulation No. 78 of 2015 concerning Wages. Jakarta: Minister of Law and Human Rights of The Republic of Indonesia.

Provan, K. G., \& Kenis, P. (2008). Modes of network governance: Structure, management, and effectiveness. Journal of Public Administration Research and Theory, JPART, 18,229-252.

Provan, K. G., \& Milward, H. B. (2001). Do networks really work? A framework for evaluating public-sector organizational networks. Public Administration Review, 61(4)

$\mathrm{Qu} \&$ Loosemore. (2013). A meta-analysis of opportunistic behaviour in publicprivate partnerships: Manifestations and antecedents. In S. D. Smith \& D. D. Ahiaga-Dagbui (Eds.), Proceeding 29th Annual ARCOM Conference (pp. 415424). UK: Association of Researchers in Construstion Management.

Rogers, Todd, Howard-Pitney, B., Feighery E. C., Altman, D. G., Endres, J. M., \& Roeseler, A. G. (1993). Characteristics and participant perceptions of tobacco control coalitions in California. Health Education Research, Theory \& Practice, 8, 345-57.

Taufiq, M., \& Hidayat, Z. (2011). Kajian hukum terhadap perselisihan pemutusan hubungan kerja secara sepihak pada perusahaan. Jurnal WIGA, 2(2).

The President of The Republic of Indonesia. (2003). Law Number 13/2003 concerning Manpower. Jakarta.

Utami, T. K. (2013). Peran serikat pekerja dalam penyelesaian pemutusan hubungan 
kerja. Jurnal Wawasan Hukum, 28(1), 675686.

Wanna, J., \& O'Flynn, J. (2008). Collaborative governance: A new era of public policy in Australia. Australia: The Australian National University.

Bupati Bandung Barat. (2016). West Bandung Regent Decree No. 560/Kep.
462-Dinsoskertrans/2016 concerning the Formation of Wage Council and Wage Council Secretariat of West Bandung Regency for 2014-2017. Bandung Barat.

Yaffee, S. L., \& Julia W. (2003). Collaborative ecosystem planning processes in the United States: Evolution and challenges. Environments, 31(2), 59-72. 